\title{
PENERAPAN METODE PROBLEM BASED LEARNING DALAM PELAJARAN AL - ISLAM II DI FAKULTAS TEKNIK UNIVERSITAS MUHAMMADIYAH JAKARTA
}

\author{
Nelfiyanti, Didi Sunardi \\ Program Studi Teknik Industri \\ Universitas Muhammadiyah Jakarta, Jakarta Pusat \\ nelfiyanti@ftumj.ac.id
}

\begin{abstract}
Abstrak
Proses pembelajaran semakin lama semakin menemukan metode yang baru yang menuntut mahasiswa lebih aktit bahkan superaktif dalam belajar sehingga mahasiswa dapat memahami materi apa yang diinginkan dari silabus matkul Al-islam II. Metode ini dinamakan PBL (Problem Based Learning). Tahapan yang dilakukan dalam penelitian ini adalah perencanaan, pelaksanaan, pemantauan, serta evaluasi adan refleksi. Dalam penelitian ini, diharapkan dapat menigkatkan minat baca dan belajar mahasiswa baik yang dilakukan didalam kelas maupun diluar kelas. Karena proses pembelajaran dengan metode PBL lebih banyak menganalisa suatu kasus yang menuntuk pastisipasi semua mahasiswa dalam proses belajar. Dengan penerapan metode PBL yang dilakukan membuat mahasiswa termotifasi untuk lebih aktif dalam memecahkan suatu masalah yang ada. Dan ini sudah dapat dibuktikan dengan aktifnya mahasiswa dalam tim kelompok dan persentasi untuk mempertahankan solusi yang diberikan.
\end{abstract}

Kata kunci : Pembelajaran, Al-Islam II, PBL, Pemahaman, Student Center

\section{PENDAHULUAN}

Dalam sistem belajar saat ini baik di bangku sekolah maupun di bangku perkulihaan, masih banyak yang menerapkan sistem pengajaran yang berpusat dari pengajar (teacher centered) menuju pembelajaran yang terpusat ke pada siswa dan mahasiswa (student centered). Sistem yang digunakan saat ini lebih banyak menuntut pengajar lebih aktif dan kreaktif dalam megembangkan proses pembelajaran. Sehingga dapat menghasilkan anak didikan yang berprestasi melalui kegiatan- kegiatan yang jelas dan menyenangkan sehingga anak didik damapt mengembangkan potensi belajar secara optimal. Fakultas teknik Universitas Muhammadiyah Jakarta memiliki tujuh jurusan yaitu ; Teknik mesin, teknik industri, teknik kimia, teknik informatika, teknik arsitek, teknik elektro, teknik sipil dan d3 otomotif. Dimana mayoritas pengajar menggunakan sistem belajar yaitu pengajar yang mengarahkan dan memberitahu apa yang ada dan yang diinginkan dari matakuliah tersebut sehingga anak didik mendengarkan dan memahami apa yang disampaikan oleg pengajar. Sistem belajar seperti ini banyak menimbulkan kejadian- kejadian yang tidak diharapkan, diantaranya adalah anak didik tidur saat pengajar peneerangkan, anak didik bercerita dengan temannya yang ada disebelah maupun di depan dan belakang dan ada juga yang melamun saat proses belajar.

$\mathrm{Al}$ - Islam II merupakan matakuliah umum yang ada di setiap jurusan. Dimana mata kuliah Al-islam II berisikan tentang sejarah, aturan- aturan dalam agama. Semua materi yang disampaikan bersifat teoritis yang mana proses pembelajaran masih menggunakan pengajar lebih banyak menarahkan dan menyampaikan apa- apa saja materi yang berhubungan dengan Al- Islam II sementara anak didik mendengarkan. Proses pembelajaran ini tidaklah efektif jika dilihat dari kondisi yang ada saat ini. Dikarenakan anak didik lebih banyak mendengarkan dan kebanyakkan juga tidak memahami apa yang disampaikan dikarenakan anak didik lebih banyak bercerita dengan teman yang disebelahnya bahkan lebih parah lagi ada yang tidur selama proses belajar berlangsung. Disini terlihat tidak semua anak didik aktif mendengarkan dan bertanya dalam proses belajar. Permasalahan yang timbul berimbas pada prestasi yang didapat anak didik untuk matakuliah Al- Islam II. Kebanyakkan anak didik mendapatkan nilai di bawah rata- rata. Padahal matakuliah AlIslam II merupakan mata kuliah wajib yang ditetapkan oleh Universitas. Oleh sebab itu, 
pada kesempatan ini peneliti ingin melakukan suatu penelitian tentang Analisa Penerapan Metode Problem Based Learning (PBL) pada Pelajaran Al- Islam II Fakultas Teknik Universitas Muhammadiyah Jakarta. PBL merupakan metode belajar yang menggunakan masalah sebagaai langkah awal dalam mengumpulkan dan mengintegrasikan pengetahuan baru. Metode ini juga berfokus pada keaktifan peserta didik dalam kegiatan pembelajaran. Peserta didik tidak lagi diberikan materi belajar secara satu arah seperti pada metode pembelajaran konvensional. Dengan metode ini, diharapkan peserta didik dapat mengembangkan pengetahuan mereka secara mandiri.

\section{LANDASAN TEORI}

\section{A. Problem Based Learning}

Problem Based Learning (PBL) adalah metode pembelajaran yang dipicu oleh permasalahan, yang mendorong mahasiswa untuk :

a. Belajar dan bekerja kooperatif dalam kelompok untuk mendapatkan solusi

b. Berfikir kritis dan anlitis

c. Mampu menetapkan serta menggunakan sumber daya pembelajaran yang sesuai.

Problam Base Learning adalah proses pembelajaran berbasis suatu kasus yang menyajikan masalah autetik dan bermakna sehingga diharapkan mahasiswa dapat menyelesaikan dan menemukan solusi untuk kasus teersebut. Dalam PBL, dosen berperan sebagai yang memberikan kasus, memfasilitasi penyelidikan dan interaksi mahasiswa.

Menurut techer and Education Development ( 2002, hal 116) Problem Based Learning (PBL) is method of learning in wich learners first encounter a problem followed by a systematic, learned - centered inguiry and reflection process. Maksudnya adalah Problem Based Learrning merupakan suatu metode pembelajran di mana yang belajar (pembelajar) bertemu dengan suatu masalah yang tersusun secara sistemtis, penemuan berpusat pada pembelajar dan proses refleksi.

Sedangkan Rusman (2010) menyatakan PBL merupakan proses pembelajaran yang berbasiskan suatu masalah yang inovasi dikarenakan disini kemampuan mahasiswa benr- benar harus optimal dalam berfikir untuk menyelesaikan suatu masalah tersbut secara sistematis dan dikerjakan berkelompok.

Kriteria dari metode PBL adalah :

a. Pembelajaran yang dipicu permasalahan

b. Informasi yang diperlukan tidak dijelaskan terlebih dahulu

c. Masalah diselesaikan dalam kelompok kecil

d. Diskusi kelompok difasilitasi olrh fasilitator

Alder dan Milne, (1997) mendefinisikan Problem Based Learning merupakan metode yang berfokus kepada identifikasi permasalahan serta penyusunan kerangka analisis dan pemecahan. Metode ini dilakukan dengan membentuk kelompokkelompok kecil, banyak kerja sama dan interaksi, mendiskusikan hal-hal yang tidak atau kurang dipahami serta berbagi peran untuk melaksanakan tugas dan saling melaporkan.

PBL adalah suatu yang menggunakan masalah dunia nyata sebagai suatu konteks bagi siswa untuk belajar berfikir kritis dan ketrampilan pemecahan masalah, serta untuk memperoleh pengetahuan yang esensial dari mata pelajaran. PBL memiliki gagasan bahwa pembelajaran dapat dicapai jika kegiatan pendidikan dipusatkan pada tugas- tigas atau permasalahan yang auntentik dan dipersentasikan dalam konteks. Berdasarkan pendapat tersebut dapat dinyatakan bahwa PBL merupakan sebuah model pembelajaran alternative yang dapat diterapkan oleh para pendidik.

Tujuan pembelajaran berdasarkan masalah ada tiga, yaitu membantu siswa mengembangkan ketrampilan- ketrampilan penyelidik dan pemecahan masalah, member kesempatan kepada siswa mempelajari pengalaman- pengalaman dan peranperan orang dewasa, dan memungkinkan siswa meningkatkan sendiri kemampuan 
berfikir mereka dan menjadi siswa mandiri. Adapun tujuan PBL menurut rusman $(2010,238)$ yaitu penguasaan isi belajar dari disipilin heuristic dan pengembangan ketrampilan pemecahan masalah. PBL juga berhubungan dengan belajar tentang kehidupan yang lebih luas (lifewide learning), ketrampilan memaknai informasi, kolaborasi dan belajar tim dan ketrampilan berfikir reflektif dan evaluative.

\section{B. Langkah- langkah Model Pembelajaran Problem based Learning}

Ada lima proses dalam penerapan metode PBL dan perilaku yang dibutuh oleh pengajar . Adapun tahapan- tahapan tersebut adalah (Sugiyanto, 2010):

Tabel 1 Sintaksis Model Pembelajaran berbasis masalah

\begin{tabular}{|c|c|c|}
\hline & Fase & Perilaku Pengajar \\
\hline Fase I & $\begin{array}{lr}\text { Memberikan orentasi } & \text { tentang } \\
\text { permasalahannya } & \text { kepada } \\
\text { mahasiswa } & \end{array}$ & $\begin{array}{l}\text { Guru membahas tujuan pembelajaran, } \\
\text { mendeskripsikan dan memotivasi anak didik } \\
\text { agar terlibat dalam kegiatan mengatasi } \\
\text { masalah yang ada. }\end{array}$ \\
\hline Fase 2 & $\begin{array}{l}\text { Mengorganisasikan anak didik } \\
\text { untuk meniliti }\end{array}$ & $\begin{array}{l}\text { Guru membantu anak didik untuk } \\
\text { mendefenisikan dan mengorganisasikan } \\
\text { tugas- tugas belajar yang terkait dengan } \\
\text { pemrmasalahannya. }\end{array}$ \\
\hline Fase 3 & $\begin{array}{l}\text { Membantu menyelidiki secara } \\
\text { mandiri atau kelompok }\end{array}$ & $\begin{array}{l}\text { Guru mendorong anak didik untuk } \\
\text { mendapatkan informasi yang tepat, } \\
\text { melakukan eksperimen dan mencari } \\
\text { penjelasan serta solusi untuk penyelesaian } \\
\text { masalah tersebut. }\end{array}$ \\
\hline Fase 4 & $\begin{array}{l}\text { Mengembangkan dan } \\
\text { mempresentasikan hasil kerja }\end{array}$ & $\begin{array}{l}\text { Guru membantu anak didik dalam } \\
\text { merencanakan dan menyiapkan hasil- hasil } \\
\text { yang tepat, seperti laporan, rekaman vidio } \\
\text { dan model- model yang mebantu mereka } \\
\text { untuk menyampaikan kepada orang lain } \\
\text { hasil yang mereka dapatkan untuk } \\
\text { menyelesaikan masalah tersebut. }\end{array}$ \\
\hline Fase 5 & $\begin{array}{l}\text { Menganalisis dan mengevaluasi } \\
\text { proses mengatasi masalah }\end{array}$ & $\begin{array}{l}\text { Guru membantu anak didik untuk } \\
\text { melakukan refleksi terhadap inverstigasinya } \\
\text { dan proses- proses yang mereka gunakan. }\end{array}$ \\
\hline
\end{tabular}

Sumber : Sugiyanto, 2010

Perilaku yang diinginkan dari pengajar dan anak didik, yang berhubungan dengan masing- masing fase, dideskripsikan dengan lebih terperinci yang dibagi dalam beberapa bagian :

1. Memberikan orentasi tentang permasalahan kepada siswa

Pada awal pelajaran PBL, seperti semua tipe pelajaran lainnya, pengajar seharusnya mengkomunikikan dengan jelas maksud pelajarannya, membangun sikap positif terhadap pelajaran itu, dan mendeskripsikan sesuatu yang diharapkan untuk dilakukan oleh anak didik. Untuk anak didik yang lebih muda atau belum pernah terlibat dalam PBL, pengajar harus menjelaskan prosedur- prosedur model itu secara terperinci. Hal- hal yang perlu diperhatikan adalah :

a. Tujuan utama pelajaranbukan untuk mempelajari sejumlah besar informasi baru tetapi untuk menginvestigasi berbagai permasalahan penting menjadi abak didik yang mandiri. Untuk anak didik yang lebih muda, konsep ini dapat dijelaskan sebagai pelajaran bagi mereka untuk menemukan sendiri makna berbagai hal. 
b. Permasalahan atau pertanyaan yang diinvestigasikan tidak memiliki jawaban yang mutlak :benar" dan sebagian besar permasalahan kompleks memiliki banyak solusi yang kadang- kadang saling bertentangan.

c. Selama fase investigasi pelajaran, anak didik akan didorong untuk melontarkan pertanyaan dan mencari informasi. Pengajar akan memberikan bantuan, tetapi anak didik mesti beruaha bekerja secara mandiri atau dengan tim.

d. Selama fase analisi dan penjelasan pelajaran, anak didik akan didiring untuk mengespresikan ide- idenya secara terbuka dan bebas. Tidak ada ide yang akan ditertawakan oleh pengajar maupun teman sekelas. Semua anak didik akan diberikan kesempatan untuk berkontribui dalam investigasi dan untuk mengepresikan ide- idenya.

2. Mengorganisasikan anak didik untuk mandiri

PBL mengharuskan guru untuk megembangkan ketrampilan kolaborasi diantara anak didik dan membantu mereka untuk menginvestigasi masalah secara bersamasama. PBL juga mengharuskan pengajar untuk membantu anank didik untuk merencanakan tugas investigasi dan pelaporannya.

3. Perencanaan Kooperatif

Setelah anak didik menerima orentasi tentang situasi permasalahan yang dimaksud dan telah membetuk tim- tim studi, pengajar dan anak didik harus meluangkan waktu yang cukup untuk menetapkan sub- sub topik, tugas- tugas investigasi, dan jadwal yang spesifik untuk sebagian proyek. Tugas perencanaannya adalah membagi situasi permasalahan yang lebih umum menjadi sub- sub topik yang tepat dan kemudian membantu anak didik untuk memutuskan sub- sub topik mana yang akan diselidiki.

4. Investigasi, pengumpulan data dan eksprimentasi

Investigasi yang dilakukan secara mandiri berpasangan atau dalam tim kelompok kecil adalah inti dari PBL. Meskipun setiap situasi masalah membutuhkan teknik investigasi yang agak berbeda. Kebanyakkan melibatkan proses mengumpulksn data dan ekperimentasi. Pembuatan hipotesis dan penjelasan dan memberikan solusi.

5. Mengembangkan Hipotesis, menjelaskan dan memberi solusi

Setelah anak didik mengumpulkan data yang cukup dan melaksanakan eksperimen terhadap fenomena yang mereka selidiki, mereka akan menarkan hipotesis, penjelasan ini. Selama fase ini berlangsung, pengaja mendorong anak didik untuk mengeluiarkan segala ide dan menerima sepenuhnya ide- ide itu. Pengajar terus memnerikan pertanyaan yang membuat anak didik memikirkan tentang ketakutan hipotesis dan solusi mereka tentang kualitas informasi yang telah mereka kumpulkan. Pengajar harus selalu mendukung dn memberikan contoh pertukaran ide- ide ecara bebas dan mendorong untuk menyelesaikan pemasalahan lebih sistematis.

\section{METODOLOGI PENELITIAN}

Adapun uraian tahapan dari metodelogi penelitian :

a. Mulai

Melakukan tahapan awal penelitian untuk melihat kondisi mahasiswa saat sekarang ini.

Bagaimana keatifitasan yang dijalani oleh mahasiswa.

b. Penelitian awal

Melakukan survey awal dengan melakukan wawancara dan menilai cara belajar mahasiswa yang lagi berjalan saat ini. Seperti apa kegiatan yang berjalan.

c. Studi Literatur

Mencari sebanyak- banyaknya litertatur yang berhubungan dengan penerapan PBL untuk membantu dalam proses ngajar dan belajar mahasiswa dan dosen. 
d. Pengumpulan data

Data yang dibutuhkan bersifat kuantitatif yaitu melihat secara langsung system mahasiswa belajar dan melakukan penilaian terhadap mahasiswa dengan penerapan metode PBL. Kuisioner disebar hanya bersifat untuk menilai sesama mahasiswa. Bagaimana pemahaman mereka terhadap materi yang diberikan, menelaah dan menyelsaikan masalah yang ada.

e. Pengolahan data

Data yang diolah adalah data kuantitatif dari wawancara dan penlian secara langsung terhadap mahasiswa dengan penerapan PBL. Apakah ada perubahan atau tidak pada minat belajarnya.

f. Analisa PBL

Melakukan analisa terhadap penerapan PBL

g. Kesimpulan

Menarik suatu kesimpulan dari penerapn PBL yang disesuaikan denganj tujuan dari penelitian.

\section{HASIL DAN PEMBAHASAN}

Teknik analisis data yang dilakukan pada pene;litian ini adalah teknik deskriftif, dimana perestasi mahasiswa dianlisi berdasarkan tingkat penguasaaan materi yang dibahas secara kelompok dan dipersentasikan di depan kelas.

Tahapan dalam pengumpulan data :

1. Partisipasi mahasiswa dilakukan dengan cara observasi

2. Prestasi belajar dengan cara melakukan tes

3. Tanggapan mahasiswa dilakukan dengan cara penilaian kuisioner dan wawancara Adapaun rekapan penilaian kuisioner dari mahasiswa untuk mahasiswa adalah :

Tabel 2. Borang penilaian Kontribusi Anggota Kelompok

\begin{tabular}{l|r|r|r|r|r|r}
\hline \multicolumn{1}{c}{ Nama Anggota Kelompok yang dinilai } & \multicolumn{3}{|c|}{ Nilai dalam angka } & \\
\cline { 2 - 6 } & 1 & 2 & 3 & 4 & 5 & 6 \\
\hline Memberikan lembar tugas mandiri yang singkat dan & 3 & 4 & 9 & 18 & 11 & 6 \\
jelas & 3 & 3 & 16 & 17 & 5 & 7 \\
Menjelaskan konsep dan opini dengan jelas & 3 & 2 & 7 & 17 & 15 & 7 \\
$\begin{array}{l}\text { Mendengarkan untuk memahami materi dan menjaga } \\
\text { diskusi tetap pada isu terkait }\end{array}$ & 3 & 4 & 15 & 13 & 12 & 4 \\
Mengajak anggota lain memberi umpan balik dan & 3 & 3 & 12 & 21 & 5 & 7 \\
berpartisipasi dalam diskusi & 3 & & & & & \\
menilai dengan kritis informasi yang tersaji & 3 & 3 & 7 & 23 & 7 & 8 \\
berkontribusi terhadap solusi yang dihasilkan & & & &
\end{tabular}

Sumber : Pengumpulan data peneliti, 2016

Keterangan :

Nilai anggota kelompok dalam hal berikut ini, dengan menuliskan angka dalam skala 1 - 6

$\begin{array}{llllll}\text { Tidak ada } & \text { Kurang } & \text { Cukup } & \text { Bagus } & \text { Bagus sekali } & \text { terbaik } \\ 1 & 2 & 3 & 4 & 5 & 6\end{array}$


Tabel 3. Borang Penilaian Presentasi Anggota

\begin{tabular}{l|r|r|r|r|r|r|r}
\hline KRITERIA & \multicolumn{6}{|c}{ Nilai dalam angka } \\
\hline & & 1 & 2 & 3 & 4 & 5 & 6 \\
Penggunaan waktu & 0 & 2 & 29 & 40 & 35 & 0 \\
Materi presentasi jelas, singkat dan mudah dibaca & 0 & 2 & 22 & 60 & 18 & 5 \\
Melakukan kontak mata dengan penonton & 1 & 6 & 37 & 37 & 23 & 2 \\
Berbicara dengan jelas dan intonasi yang sesuai & 1 & 5 & 33 & 42 & 24 & 1 \\
Menyajikan gambar/plot/tabel agar presentasi efektif & 0 & 5 & 39 & 34 & 28 & 0 \\
Penampilan keseluruhan rapih dan sesuai & 0 & 6 & 14 & 55 & 19 & 12 \\
\hline
\end{tabular}

Sumber : Pengumpulan data peneliti, 2016

Keterangan :

Nilai anggota kelompok dalam hal berikut ini, dengan menuliskan angka dalam skala 1 - 6

$\begin{array}{llllll}\text { Tidak ada } & \text { Kurang } & \text { Cukup } & \text { Bagus } & \text { Bagus sekali } & \text { terbaik } \\ 1 & 2 & 3 & 4 & 5 & 6\end{array}$

\section{Hasil pembahasan terhadap penerapan metode Problem Based Learning}

Uraian yang didapat dari hasil pembelajaran dengan menggunakan siklus pertama adaalah penelitian dilakukan terhadap 30 orang mahasiswa. Adapun topic permasalahan yang di bahas adalah :

a. Bagaimana malaksanakan pengertian dan jenis ibadah

b. Bagaimana cara menghilangkan najis menurut tuntunan Rasulullah

c. Bagaimana melaksanakan wudhu menurut tuntunan Rasulullah

d. Bagaimana melaksanakan tayamum menurut tuntunan Rasulullah

e. Bagaimana melaksanakan mandi wajib menurut tuntunan Rasulullah

Hasil tindakan pada siklus, menunjukkan bahwa :

a. Komunikasi di antara peserta masih sangat lambat, masih menunggu arahan dan bimbingan Dosen apa yang harus dilakukan, termasuk juga dalam kemampuan untuk bertanya dan menjawab pertanyaan masih rendah baik di lihat dari jumlah mahasiswa yang aktif bertanya maupun dari bobot pertanyaan yang diajukan dan jawaban yang diberikan.

b. Kepekaan terhadap persoalan persoalan kontemporen yang berhubungan dengan materi pembelajaran masih kurang sehingga seringkali dosen memberikan wawasan yang secara perlahan berkurang pada pertemuan-pertemuan berikutnya.

c. Sikap kerjasama dengan anggota masih kurang dan lebih menonjol sikap individualnya, hal ini karena mahsiswa belum terbiasa menyampaikan pendapat dan menghargai pendapat teman dan cenderung mempertahankan pendapatnya walaupun belum tentu benar jawabannya.

d. Kemampuan dalam menalar mahasiswa masih rendah karena kurangnya kemampuan mahasiswa dalam menginterprestasikan dan mengaplikasikan pengetahuan dan pengalaman belajar yang telah dimiliki.

e. Merumuskan kesimpulan sering tidak sesuai dengan pendapat yang berkembang dalam diskusi sehingga peran dosen juga masih tampak dalam mengarahkan dan membuat kesimpulan dari hasil diskusi.

Berdasarkan hasil belajar dan observasi tindakan pada silus I dilakukan refleksi yang difokuskan upaya mendorong mahasiswa agar berani mengemukakan ide dan pendapat, berdasarkan kepada teori yang telah dipelajari. Mahasiswa diberi kesempatan seluas-luasnya untuk berargumentasi dengan hipotesa-hipotesa dan asumsi-asumsi tertentu. Peran dosen sebagai fasilitator dan jika diperlukan memberikan bimbingan dalam proses pemecahan masalah apabila mendapat hambatan dalam mencapai tujuan pembelajaran. 
Adapun deskripsi proses dan hasil pembelajaran pada siklus kedua adalah membahas topiktopik permasalahan sebagai berikut :

a) Bagaimana melaksanakan shalat wajib

b) Bagaimana melaksanakan idain

c) Bagimna melaksanakan shalat berjama'ah

d) Bagaimana melaksanakan shaat jum'at

Kondisi KBM pada siklus kedua ini menunjukkan bahwa:

a) Dalam diskusi mahasiswa terlihat lebih aktif dan sistematis daln lebih berani dalam mengemukakan ide dan pendapatnya. Komuniksi yang terjdi di antara peserta diskusi lebih baik dengan dibuktikan mereka terlihat ada timbale balik dalam berargumentasi sehingga diskusi terlihat lebih demokratis dibandingkan dengan diskusi dalam siklus I.

b) kemampuan mahasiswa dalam memberikan contoh contoh ril dalam kehidupan masyarakat juga telah terlihat walaupun belum mampu mengungkapkannya delam bentuk yang lebih sistematis.

c) Dalam diskusi kelas masih terlihat ada dominasi dari beberapa mahasiswa tertentu dalam mengemukakan pendapat sehingga belum terlihat yang mengemukakan pendapat secara merata dan intensif.

d) Dalam merumuskan hasil diskusi sudah terlihat lebih baik tetapi belum optimal. Sehingga peran dosen dalam merumuskan hasil diskusi sudah mulai berkurang.

Deskripsi proses dan hasil pembelajaran siklus ketiga. Pelaksanaan tindakan pada siklus ketiga ini difokuskan pada upaya untuk meningkatkan partisipasi mahasiswa dalam KBM secara keseluruhan.

Adapun topik permasalahan kontektual yang dibahas adalah:

a) Bagaimana melaksanakan shalat menurut tuntunan rasulullah

b) Bagaimana melaksanakan puasa sesuai dengan tuntunan rasulullah

c) Bagaimana mengitung zakat mal

d) Bagaimana melaksanakan haji

Kondisi KBM pada siklus ketiga dapat diuraikan sebagai berikut:

a. Komunikasi dalam diskusi telah berjalan baik, mahasiswa telah memiliki kemampuan dalam menyampaikan pertanyaan dan mengemukakan pendapat dengan baik. terampil dan sistematis dalam mengemukakan ide, pertanyaan maupun jawaban berdasarkan teori dan pengalaman belajar yang dimiliki.

b. Mahasiswa telah mampu memberikan contoh-contoh riil dalam mengungkapkan fenomena aktual dalam masyarakat sehubungan dengan permasalahan yang dibahas. Upaya pengungkapan ide dan simpulan permasalahan terurai secara sistematis dan operasional sehingga proses pembelajaran berlangsung dalam suasana yang kondusif.

c. Diskusi kelas berlangsung secara demokratis (tidak lagi didominasi oleh mahasiswa tertentu) dengan bobot pertanyaan, jawaban dan saran telah lebih baik yang merupakan integrasi dari sejumlah konsep dan teori yang telah dipelajari.

d. Mahasiswa telah mampu merumuskan hasil diskusi serta membuat prediksiprediksi berdasarkan asumsi-asumsi tertentu.

\section{Penilaian Kontribusi anggota Kelompok dan Penilaian presentasi anggota}

Dari kuisioner yang disebarkan dapat diberikan suatu penilaian bahwa untuk masingmasing criteria kegiatan yang dilakukan berada pada posisi ke 4 yaitu mahasiswa mayoritas bagus. 
Tabel 4. hasil rekapan penilaian anggota kelompok :

\begin{tabular}{l|r|r|r|r|r|r}
\hline \multicolumn{1}{c}{ Nama Anggota Kelompok yang dinilai } & \multicolumn{3}{c|}{ Nilai dalam angka } & \\
\cline { 2 - 6 } & 1 & 2 & 3 & 4 & 5 & 6 \\
\hline Memberikan lembar tugas mandiri yang & 3 & 4 & 9 & 18 & 11 & 6 \\
singkat dan jelas & 3 & 3 & 16 & 17 & 5 & 7 \\
Menjelaskan konsep dan opini dengan jelas & 3 & 2 & 7 & 17 & 15 & 7 \\
Mendengarkan untuk memahami materi dan menjaga & & & & & & \\
diskusi tetap pada isu terkait & 3 & 4 & 15 & 13 & 12 & 4 \\
Mengajak anggota lain memberi umpan balik dan & 3 & 3 & 12 & 21 & 5 & 7 \\
berpartisipasi dalam diskusi & & & & & & \\
menilai dengan kritis informasi yang tersaji & 3 & 3 & 7 & 23 & 7 & 8 \\
berkontribusi terhadap solusi yang & 18 & 19 & 66 & 109 & 55 & 39 \\
dihasilkan kelompok & &
\end{tabular}

Sumber : pengolahan data, 2016

Tabel 5. hasil penilaian presentasi anggota

\begin{tabular}{l|r|r|r|r|r|r}
\hline KRITERIA & \multicolumn{5}{c}{ Nilai dalam angka } \\
\cline { 2 - 6 } & 1 & 2 & 3 & 4 & 5 & 6 \\
\hline Penggunaan & 0 & 2 & 29 & 40 & 35 & 0 \\
waktu & & & & & & \\
Materi presentasi jelas, singkat dan & 0 & 2 & 22 & 60 & 18 & 5 \\
mudah dibaca & 1 & 6 & 37 & 37 & 23 & 2 \\
Melakukan kontak mata dengan & & & & & & \\
penonton & 1 & 5 & 33 & 42 & 24 & 1 \\
Berbicara dengan jelas dan intonasi & & & & & & \\
yang sesuai & 0 & 5 & 39 & 34 & 28 & 0 \\
Menyajikan gambar/plot/tabel agar & & & & & & \\
presentasi efektif & 0 & 6 & 14 & 55 & 19 & 12 \\
Penampilan keseluruhan rapih & 2 & 26 & 174 & 268 & 147 & 20 \\
dan sesuai &
\end{tabular}

Sumber : Pengolahan data, 2016

\section{Analisa pembahasan}

Dari penerapan metode Problem based Learning (PBL) dapat ditarik suati analisa yaitu :mahasiswa muhamadiyah Jakarta kafultas teknik memiliki minat belajar yang bgaus dengan memaksa mereka untuk lebih aktif dalam memecah masalah yang diberikan. Dengan sendirinya memerka dapat memahami secara langsung materi yang ada pada matakuliah Al- Islam II.Akan tetapi ada juga beberapa mahasiswa yang tidak atuas dalam belajar. Mahasiswa hanya bersifat seperti pendengar saja dari apa yang disampaikan oleh temannya bahkan ada yang tidak bisa menyelesaikan problem yang ada. Dengan menerapkan PBL satu kelompok yang doiberi tugas harus mau bekerjasama dalam menyelesaikan masalah yang diberikan oleh dosen sehingga menemukan jawaban dari masalah tersebut. 


\section{KESIMPULAN DAN SARAN}

\section{A. Kesimpulan}

Adapun kesimpulan yang dapat ditarik dari penelitian ini adalah :

1. Dari kegiatan pembelajaran matakuliah Al- Islam II dapat dilihat bahwa kreatifitas mahasiswa sangat kurang dalam memberikan gagasan- gagasan, jawaban, dan pertanyaan terhadapat materi yang disampaikan. Mahasiswa hanya bersifat menerima saja dan menjadi pendengar sejati saja.

2. Metode PBL dapat diterapkan terhadap matakuliah AL- Islam II. Hal ini dikarenakan matakuliah Al- islam II bersifat teori yang mwngharuskan mahasiswa lebih aktif bahkan proaktif terhadap materi yang disampaikan.

3. Setelah metode PBL diterapkan mahasiswa diwajibkan lebih aktif dalam penyerapan materi yang disampaikan berdasarkan dari poin- poin permasalahan yang dibroikan dan di crenah serta di olah oleh mahasiswa sendiri secara tim sehingga semua mahasiswa harus aktif.

\section{B. Saran}

Saran yang dapat diberikan :

1. Metode PBL dapat diterapkan untuk matakuliah yang bersifat hitungan untuk meihat kemampuan mahasiswa dalam menelaah soal yang ada sehingga mahasiswa harus lebih akitf.

2. Pembagian poin- poin masalah lebih dipertajam.

\section{DAFTAR PUSTAKA}

Amir Taufik. 2009. Inovasi Pendidikan Melalui Problem based Learning. Penerbit: Prenada Media. Indonesia.

Mulia kamarza. 2014.Studen-Centered Learning di Perguruan Tinggi dengan Menerapkan Problem-Based Learning (PBL).Penerbit : Departemen Teknik Kimia. Universitas Indonesia.

Rokhanah Siti. 2007. Model pembelajaran Ilmu Pengetahuan Sosial di MTS. Penerbit : Balai Diklat Keagamaan Semarang. Semarang.

Sunardi Didik. 2014. Modul Pembelajaran Al- Islam II. Departemen Teknik Industri. Universitas Muhammadiyah Jakarta. 
